\title{
Report on East-Asian Cinema
}

\author{
By Toh, Hai Leong \\ Fall 1997 Issue of KINEMA
}

\section{EMERGING TRENDS: A PERSONAL VIEW}

From Singapore three out of four of its cinematic efforts produced in the last two years were shown in Penang's First East Asian Film and Television Festival held in Pulau Pinang (Malaysia) from 27th August to 3rd September 1997. These were Lim Suat Yen's The Road Less Travelled, Eric Khoo's 12 Storeys and Ong Keng Sen's Army Daze. The film not included was the sensationalistic Dog or God by Hugo Ng. Singapore's film history of only two years makes it still too early to observe any emerging trend in terms of themes or preoccupations, much less trends that are likely to influence other filmmakers.

Nevertheless, the island-state, better known for its clean, efficient and scrupulous government, is proud to have produced four features to date. A horrendous attempt at filmmaking was first made by beauty pageant promoter Errol Pang in 1991. Going by the half-baked name of Medium Rare and based loosely on the infamous ritual child killings of Adrian Lim which shocked Singapore, this non-entity of a film is now gladly forgotten.

Lim Suat Yen's The Road Less Travelled and Khoo's 12 Storeys are works which show considerable promise. The former is about the thwarted ambitions of four aspiring singers while the latter is a much-hyped and overrated story about the alienated lives of the inhabitants of an HDB (Housing Development Board subsidised) flat, the government-subsidized housing in which the majority of Singaporeans live.

Although there is no trend to be discerned in these films, the filmmakers do have one thing in common, and that is that both the talented Lim and Khoo had both dabbled in making shorts before moving on to feature filmmaking. On the other hand, Ong Ken Seng comes from a theatrical background, serving as the local TheatreWorks' artistic director before turning filmmaker. His film Army Daze is a product of commercial dictates. The story about a group of romping recruits is an adaptation of a play by local playwright Michael Chiang which itself has been highly successful in Singapore even after many runs over the past few years. So why not turn the play into a film? Cathay Organisation, the film's producer, took a chance and it worked, earning the company a tidy sum of money.

Khoo and Lim seem to be following the footsteps of other young and idealistic filmmakers in the 1980s from South Korea, Hong Kong and Japan who were trained in foreign film schools. The trend was to experiment with self-expression and personal statements via light and portable video equipment such as the viewcam, VHS camcorder, Hi8 video, or if they could afford it, $16 \mathrm{~mm}$ and Betacam. Initially, the common threads linking their videos were features such as animation, stop-motion and experimental pantomime acts lasting anywhere from one minute to nearly an hour.

Recently, students of the Ngee Ann Polytechnic in Singapore have been making excellent 16mm shorts of about fifteen or twenty minutes for budgets as low as SGD 1,500 to SGD 2,000. Moreover, the quality of their editing is on a par with professional standards. Likewise, students of Mass Communication programmes in Penang are also making interesting shorts. All considered, there is a definite trend in Singapore and Malaysia of youngsters making video shorts and $16 \mathrm{~mm}$ short films.

In Hong Kong where filmmaking has a fifty-year tradition and where the government subsidizes the hefty costs of the student $35 \mathrm{~mm}$ film production, Fruit Chan has made a brilliant debut with his naturalistic film Made in Hong Kong (Xianggang Zhizao, Special Jury Prize at the Locarno Film Festival 1997) about a triad boy whose lack of education condemns him to a life without a future. The film was shown out of competition at this year's 21st Hong Kong International Film Festival and yet it surpassed some of the works of the Asian masters in the main programme!

Now that the socialist-capitalist Mainland Chinese have taken over Hong Kong, the latter is enjoying the return of fantastical James Bond-like thrillers (e.g. Aces Go Places popularised in the 1980s by Cinema City's Karl Mak and Dean Shek) and a remake of Ching Siu-tung's A Chinese Ghost Story in animation 
form. These two film genres became trend-setters for lesser imitators. In addition, a spate of ghost-encounter films like Till Death Do Us Laugh, 24-Hour Ghost Story, Satan Returns and others of that ilk produced by prolific schlock filmmaker Wong Ching show a fascination with haunting -- a subject that may somehow be connected with the feeling that the Mainland Chinese past has now caught up with the former British Colony.

An interesting case in point is Derek Chiu's excellent court drama, Final Justice, which looks set to spawn a new trend. The story is about a Roman Catholic priest (Lau Ching-wan in an understated performance) whose vocation is seriously jeopardised when an obsessed woman charges him with rape. Rape, in this case, is a metaphor for a newly re-possessed Hong Kong, who like the priest, shows a weak resolution and an unwillingness to fend for itself.

Early in the 1980s, the highly reactive Hong Kong cinema reflected its jitters about the impending handover to the Mainland Chinese by producing the nonsensical (mo-lei-tau) comedies of Stephen Chow Sing Chi; the hero's films of John Woo, Ringo Lam and Chow Yun-fat; Tsui Hark and Ching Siu-tong's James Bond-like dramas in the guise of the period Swordsman genre. The adventures of Wong Fei-hung, a mythical martial arts hero popularised by Tsui Hark were re-packaged into the figure of Fong Sai Yuk, a series directed by Yuen Kwai. This Robin-Hood character is also a martial arts exponent who deals death blows to imperialism, corruption, power abuse and local chauvinism. As well, Tsui Hark's 1995 remake of Chang Cheh's Swordsman genre film The Blade (Dao) failed to impress. This, however, has been Tsui's only failure.

Meanwhile, the deluge of Category III adult erotica, produced and bankrolled by the triads from the 1980s to the mid-1990s is slowly losing ground in the local film industry as triad members move their base to the Chinatowns of western countries.

As for Mainland Chinese cinema, the world-renowned Fifth Generation Chinese filmmakers, though showing great promise in the years between 1987 and mid-1995, has lost its hold on younger audiences. Directors like Zhang Yimou, Chen Kaige, Tian Zhuangzhuang and even Wu Ziniu kept on using the Japanese Occupation and the Cultural Revolution (1966-76) as their main source of inspiration at the cost of boring and alienating China's youths who mostly grew up after 1976.

In spite of the Fifth Generation's fame, the younger, more educated and sophisticated audiences have tended towards the earth-bound Sixth Generation directors like Zhang Yuan, Guan Hu, Wu Wenggang and others who explore contemporary issues like restless youths, exile mentality, urban anomie and other social problems such as prostitution, drug abuse, promiscuity and even the taboo subject of homosexuality as epitomised in Zhang Yuan's East Palace, West Palace. Personally, I like Zhang Yuan not because he is a good friend but because he, as a single rebel filmmaker, has defied the Chinese authorities by making an unflattering cinema-vérité story about a dysfunctional family of alcoholics in his 1996 film Sons (Erzi).

After experimenting with new styles and forms in their student video works, the Koreans, upon maturity, have returned to their traditional angry filmmaking to comment on the tumultuous state of political corruption, military and secret police repression (e.g. Chang Sun-woo's A Petal and Kim Hong-jun's Rosy Life) or on the tragedy of a Korea whose division goes profoundly beyond politics (exemplified by Im Kwontaek's Taebaek Mountains and Park Kwang-su's To the Starry Island). Yet another approach is to retreat into spiritual introspection and the themes of angst to come to terms with being human, such as Chang's Hwa-Om-Kyong (1993) and Why does the Bodhidharma Go East?

Last but not least, Japanese cinema is showing a discernible trend of actors-turned-directors like Takeshi (Beat) Kitano and Tampopo's famous Juzo Itami who make interesting films with shocking brutality. Kitano has made the most violent yakuza (cop) film to date called Violent Cop followed by Sonatine. His latest autobiograhpical film Kids Return must have influenced younger directors like Sogo Ishii.

\section{Author Information}

TOH Hai Leong is a Singapore-based freelance film critic and filmmaker (Zombie Dogs, 2005) who writes for independent film publications such as Screen International and World Paper. He has covered the Hong 
Kong International Film Festival since 1985 and specializes in the cinemas of Hong Kong, Taiwan, China, Korea and Japan. 